\title{
YOKSULLUK VE SUÇ: DOĞRUSAL OLMAYAN BİR İLIŞKI
}

\author{
Poverty and Crime: An Indirect Connection
}

\section{Reşat AÇIKGÖZ* \\ ÖZET}

$\mathrm{Bu}$ çalışmada, yoksulluk ve suç arasındaki ilişki ele alınmaktadır. Genel kanı, yoksulluğun suça sebep olduğu yönündedir. Ancak, yoksulluk gibi, suç da tek bir faktörle izah edilemez. Suçluluğun oluşumunda geçmiş yaşantılar, aile ortamı, arkadaşlık çevresi, uyuşturucu ve alkol gibi çeşitli alışkanlıklar etkili olduğu gibi, yoksulluğun meydana gelmesinde de birçok faktör etkili olmaktadır. Yoksulluk, suç işlemeyi etkileyen unsurlardan biridir; fakat ana belirleyici ve tek faktör değildir. Yoksulluğun suçlu davranışlara yol açması da, homojen bir nitelik taşımaz. Yoksulluğun içinde meydan geldiği sosyo-ekonomik koşullar kültürden kültüre farklı olduğu için, yoksulluğun olduğu her yerde yoksulluğa bağlı suçlardan söz etmek mümkün değildir. Zira her yoksul olan, zorunlu olarak suç işlememekte; her suç işleyen de zorunlu olarak yoksul olmamaktadır. Bu çalışmada, yoksulluk-suç ilişkisi suç teorileri bağlamında incelenmektedir. Burada özellikle, suç teorilerinin yoksulluk vurgusu üzerinde durulmakta ve teorilerin genel bir değerlendirilmesi yapılmaktadır. Sonuçta, sebep-sonuç ilişkisi bağlamında, yoksulluk ve suç arasında bir ilişkinin kurulabileceği kabul edilmekte, ancak bu ilişkinin zorunlu olarak doğrusal bir ilişki olamayacağı ileri sürülmektedir.

Anahtar Kelimeler: Yoksulluk, suç, suç teorileri, yoksulluk kültürü, yoksulluk-suç ilişkisi.

\begin{abstract}
In this paper, the relationship between poverty and crime has been studied. The mainstream view about poverty and crime is that poverty causes crime. However, crime cannot be depicted in a single factor such as poverty. As well as the past experiences of individuals, his/her family and friendship environment, the habits such as drug and alcohol may as well cause crime; poverty is also consequence of many factors. Poverty is one of the factors that influences crime: yet it is not the main reason and only factor that causes crime. The affects of poverty on crime do not occur in homogeneous forms. Since socio-economical circumstances in which poverty exists are from culture to culture, it is impossible to mention about crimes everywhere poverty can been seen. Because neither every poor commits crime necessarily, nor all those who commit criminal behaviors are paupers. This study investigates the relationship between poverty and crime in the contexts of crime theories. In particular, it is discussed theories of crime's emphasis on poverty and evaluated in general theories of crime in several respects. Eventually, it is agreed that poverty can lead to crime in the context of cause and effect, but it is suggested that this connection is not necessary and directed.
\end{abstract}

Key Words: Poverty, crime, theories of crime, culture of poverty, poverty-crime connection.

\section{GİRIŞ}

Yoksulluk ve suç günümüzde küresel boyutlarda yaşanan ve toplumları farklı şekillerde etkileyen önemli toplumsal olgu(sorun)lardır. Geçmiş dönemlerdeki biçimlerinden oldukça farklı nitelikler sergileyen yoksulluk ve suç, bugün hem alt ve orta sınıfları hem de, kısmen de olsa, üst sinıfları etkilemektedir. Yoksulluk daha çok alt tabakadaki insanları ve dezavantajlı grupları etkilerken, suç ise toplumun her kesimindeki kişileri doğrudan veya dolaylı olarak etkilemektedir. Genel görüntü böyle olmakla birlikte, günümüz küresel dünyasında bu durumun istisnalarına bolca rastlamak mümkündür. Esnek üretimin ve teknolojik gücün egemen olduğu küresel ekonomik düzende çalışan birinin aniden işini kaybedip işsiz kalması ve dolayısıyla yoksullaşma riskiyle karşılaşması ya da işletme sahibi veya zengin birinin küresel ekonomik rekabet dayanamayıp iflas etmesi ve dolayısıyla yoksulluğa maruz kalması her zaman mümkün olduğu gibi, toplumsal ilişkilerin kişisel çıkarlar etrafında şekillendiği toplumsal mekânlarda (özellikle kentsel ortamlarda) farklı toplumsal kesimlerden kişilerin suç faaliyetleri içine girmeleri veya bu faaliyetlerin

\footnotetext{
*Yrd. Doç. Dr., Muş Alparslan Üniversitesi Sosyoloji Bölümü, MUŞ Mail: r.acikgoz@alparslan.edu.tr
} 


\section{F.Ü. Sosyal Bilimler Dergisi 2015-25/1}

kurbanları haline gelmeleri de her zaman olasıdır. Dolayısıyla, yoksulluk ve suçun günümüzde oldukça kırılgan ve değişken yapılara sahip olduğunu söylemek mümkündür.

Sebep-sonuç ilişkilerine göre ele alındığında, yoksulluk ile suç arasında bir ilişkinin var olduğu görülmektedir. Suçla ilgili literatürde bu durum sıkça dile getirilmekte ve genellikle yoksulluğun suçun en önemli nedeni olduğu belirtilmektedir. Modern toplumların karmaşık yapılarını analiz eden birçok sosyolojik kuram, yoksulluğu, suç dâhil, birçok sosyal soruna yol açan bir faktör olarak ele almıştır. Bununla birlikte, yoksulluk merkezde kalmaya devam etmesine rağmen, suçu farklı bakış açılarıyla ele alan ve başka faktörlerle izah etmeye çalışan kuramlar da mevcuttur. Etiketleme kuramı buna örnek verilebilir.

Hem yoksulluk hem de suç, çeşitli nedenlerden kaynaklanmakta ve ciddi sonuçlara yol açmaktadırlar. Her biri tek bir faktörle izah edilemez. Örneğin, yoksulluğun toplumsal, ekonomik, kültürel ve bireysel nedenleri olduğu gibi, suçun da benzer nedenleri vardır. Keza, yoksulluk boşanma, intihar, dışlanma ve yabancılaşma gibi sonuçlara yol açabildiği gibi, suçun sonucunda da benzer sonuçlar ortaya çıkabilmektedir. Buradaki önemli husus, hem sebepleri hem de sonuçları itibariyle birçok farklı faktörle ilişkili olan iki olgunun (yoksulluk ve suç) aynı zamanda birbirleriyle de yakından bağlantılı olmaları ve birbirlerini besleyen bir döngü içinde olmalarıdır. Birinin varlığı, diğerinin ortaya çıkışını zorunlu kılmaz; fakat tarihsel süreçler ve içinde yaşadığımız toplumsal koşullar ikisinin birbiriyle yakından bağlantılı olduğunu göstermektedir.

Ancak, bu bağlantı her zaman ve her yerde doğrusal bir çizgi şeklinde ortaya çıkmamaktadır. Başka bir deyişle, yoksulluğun bulunduğu her yerde suçtan veya suçun görüldüğü her yerde yoksulluktan bahsetmek her zaman doğru değildir. Zira zamana ve yere göre tarihsel ve toplumsal koşullar farklı olabilmektedir. Örneğin, yoksulluk ile suç arasındaki ilişki ülkelerin toplumsal yapılarına göre değişkenlik göstermektedir. Ülkelerin gelişmişlik düzeyleri, sınıfsal yapıları, kurumsal örgütlenmeleri, adalet/hukuk sistemleri, toplumsal norm ve değerleri, yoksulluk-suç ilişkisi üzerinde etkili olmaktadır. Zengin ülkelerle yoksul ülkeler kıyaslandığında, yoksul ülkelerdeki suç oranları zengin ülkelerdekinden fazlaysa, bu durumda suçu yoksulluk ve azgelişmişlik gibi olgularla açıklamak mümkündür. Aynı şekilde zengin ülkelerde görülen suçların büyük çoğunluğu yoksul kesimler tarafindan işleniyorsa, o zaman yine yoksulluk suçun tetikleyici unsuru olarak ele alınabilir. Fakat zengin ülkelerdeki suçluluk toplumun bütün kesimleri arasında görülüyorsa, o zaman suçun açıklanmasında başka faktörleri, örneğin toplumsal güç, sınıf çatışması, baskı ve kültür gibi unsurları da dikkate almak gerekmektedir.

Yoksulluk ve suçla ilgili olarak ülkeler arasında görülen farklılı̆̆ın bir benzeri bir ülkenin kendi içinde de, örneğin kırsal ve kentsel kesimleri arasında, zengin ve yoksul bölgeleri arasında ve farklı toplumsal kesimleri arasında da görülmektedir. Hem toplumlar arasında hem de toplumların kendi bünyelerinde taşıdıkları farklılıklardan dolayı, yoksulluk-suç ilişkisini çözümlemek için başka faktörleri de hesaba katmak gerekmektedir. Bu şekilde hem indirgemeci bir bakış açısından kurtulmuş olunur, hem de meseleyi etraflıca değerlendirme imkânı elde edilir.

\section{YOKSULLUĞUN VE SUÇUN DEĞISŞEN YÜZLERI}

Geçmiş dönemlerle kıyaslandığında, yoksulluk ve suçta önemli değişimlerin meydana geldiği görülmektedir. Değişimlerin dönüm noktası olarak modernite ve kapitalizmin eş zamanlı ortaya çıktıkları süreci göstermek mümkündür. Hem yoksulluk hem de suç için modern öncesi dönem ve modern dönem diye ikili bir sınıflandırma yapılabilir. Çünkü yoksulluk ve suçla ilgili tanımlarda, algılarda, kurumsal yapıda, dini inanışlarda ve kültürel değerlerde her iki dönem için- hem biçimce hem de mahiyetçe- oldukça farklı bir durum söz konusudur.

Modern öncesi dönemde yoksulluk, Doğu ve Batı toplumları arasında farklılıklar bulunsa da, hem bir yaşam tarzı hem de toplumun devamı için gerekli bir olgu olarak görülmekteydi. Yoksullar da çoğunlukça toplumun bütünlüğüne tehdit oluşturan potansiyel bir suçlu kitlesi olarak değil, toplumdaki herkes için işlevsel önemleri bulunan bir kitle olarak algılanmaktaydı. Balcı'nın (2007: 26) belirttiği gibi, özellikle "modern-öncesi Hıristiyan Avrupa'da yoksulların varlığı Tanrı'nın 
herkese bir armağanı, fedakârlık yapmanın, namuslu bir hayat yaşamanın, tövbe etmenin ve ilahi saadete ulaşmanın bir firsatıydı."

Modern öncesi dönemde yoksullar arasında kanaat, paylaşmak ve dayanışma gibi değerler egemen olduğundan Robert ve Rahnema (2011: 42), yoksulluğu bir yaşama sanatı olarak görmekte ve yoksulu da "kültürlerin pek çoğunda yalnızca, sayıca insanların çoğunluğunu oluşturan ve durumu- yoksul oluşu- bir yaşam biçiminden, bir yaşama ve yaşatma sanatından ayrı bir şey olmayan alçakgönüllü, sıradan insan" olarak tanımlamaktadırlar. Bu dönemin ayırt edici özelliği, yoksulluğun ekonomik ilişkilere göre tanımlanmaması ve yoksulların da ekonomik birer değer olmanın ötesinde birer insan olarak algılanmasıdır. Ancak diğer taraftan, yoksulluğun ve yoksulların durumunun dini referanslarla meşrulaştırıldığ 1 görülmektedir. Ortaçağ Avrupa'sında kilisenin öğretileri ve takip ettiği politika bunu açıkça göstermektedir. "Manevi bir değer olarak yoksulluğun yüceltilmesi, hayırseverlik uygulamasındaki bir artışla el ele gitmiştir. Yoksullar sosyal düzendeki yerlerini ve rollerini biliyorlardı: Onlar, diğerlerinin sadaka vermek yoluyla kurtuluşu satın alabilmeleri için oradaydılar” (Geremek, 1994: 18).

Kilisenin öğretisine etki eden en önemli husus, Hz. İsa'nın gönüllü yoksulluğuydu. Zira Hz. İsa kral ve Tanrı'nın oğlu olarak iktidarından feragat etmişti. Bu da zenginlikten ve iktidardan feragat edecek takipçileri için takdire şayan bir durumdu. Ortaçağ Hıristiyan Avrupa'sında yoksulların sayısının çok olmasının en önemli nedenlerinden birisi belki de bu Kilise öğretisiydi. Sadaka vermenin günahlardan arınmanın bir yolu olarak görüldüğ̈ Hıristiyan toplumda yoksulların varlığı, Geremek'e göre, Tanrı'nın kurtuluş planının doğal bir parçasıydı. Bu doktrinin klasik biçimi Life of St. Eligius'ta bulunabilir. Aziz şöyle diyordu: “Tanrı bütün insanları zengin yapabilirdi, fakat $\mathrm{O}$, bu dünyada yoksul insanların da olmasını istedi; böylece zenginler günahlarından kurutulabilirlerdi” (Geremek, 1994: 20). Bunun doğal sonucu aile, cemaat ve hayırseverlik gibi kurumların kamu kuruluşlarından daha etkili hale gelmesiydi (Fuchs, 2005: 41).

Modern öncesi dönemde yoksullar belki toplumun bütünlüğüne yönelik bir tehdit unsuru olarak görülmemekteydiler; fakat bu durum onların çeşitli şeklerde damgalanmalarının önüne geçmemekteydi. Fuchs'un (2005: 10) belirtmiş olduğu gibi, yoksullar ötekiydiler ve "yoksul" sözcügü de göçmen bir grubu veya orta sınıftan farklı bir grubu tarif etmek için kullanılan "kirli" ve "ahlâksız" gibi öteki sıfatlarla birlikte anılmaktaydı. Yoksulları öteki olarak görme, onları terbiye etmenin yollarını da beraberinde getirmişti. Yoksullar için kiliselerin yönetiminde kurulan yoksul evleri (poor house) ve yine kuruluşlarında kiliselerin etkili olduğu çalışma evleri (work house) ile yoksullar hem kontrol altına alınmaktaydı hem de disipline edilmekteydiler. Dean'e göre bu evler, "yoksullara terbiyenin, çalışkanlığın, medeniyetin aşılandığı ve çalışmanın dayatılarak bir anlamda onların benliklerinin disipline edildiği”" yerlerdi (Akt. Yılmaz, 2012: 124). Bu evlerin cezaevleri tarzında inşa edilmeleri, aslında yoksulluğun bir suç olarak algılandığını da göstermektedir. Nitekim Fuchs, (2005: 203), Yeni Yoksullar Yasasının "yoksul olma suçu" işleyenler için ceza olarak cezaevi benzeri çalışma evleri geliştirdiğini belirtmektedir. Sonuçta, 1815'e kadar Avrupa'nın çoğu yerinde, örneğin İngiltere, Fransa, Belçika, Hollanda ve bazı Alman şehirlerinde muhtaçların kapatıldığı kurumlar vardı: bakımevleri, yetimhaneler, sokak çocuğu evleri, serseri hapishaneleri vb. (Fuchs, 2005: 40-41).

Modern dönemde ise yoksulluk, gelişen sanayi kapitalizminin etkisiyle büyük bir değişime uğradı. Bu dönemde Robert ve Rahnema' ya göre, paylaşımcı ve gönüllü yoksullukların yerini "modernize yoksulluk" almıştır. Yoksulluğu üç kategoride elen alan Robert ve Rahnema (2011: 50-51), modern yoksulluğun kapitalizmle birlikte ortaya çıkan yeni üretim tarzının bir sonucu ve aynı zamanda modern ekonomik sistemin çelişkilerinin bir özeti olduğunu belirtmektedirler. Modern Pazar toplumlarının kurulmasını izleyen yıllarda Batı toplumlarında meydana gelen büyük

\footnotetext{
${ }^{1}$ Paylaşımcı yoksulluk; "kendi geleceğine saygı, eşitlik duygusu, azla yetinme, dayanışma ve yalınlık ilkelerine dayanan bir birlikte yaşamak tarzıdır. Gönüllü yoksulluk ise paylaşımcı yoksullukla aynı yalınlık ve azla yetinme ilkelerine sahiptir. Aralarındaki fark, gönüllü yoksulluğun bir halkın ortak yaşama biçimi değil, kendi zenginliklerinin bilincinde olan sıra dışı bireylerin kendi tercihleri olmasıdır (Robert ve Rahnema, 2011: 48-49).
} 


\section{F.Ü. Sosyal Bilimler Dergisi 2015-25/1}

dönüşüm (Polanyi, 2000), eş zamanlı olarak hem büyük bir zenginlik hem de kitlesel bir yoksulluk ve sefalet ortaya çıkarmıştı. Dönemin ünlü düşünürlerinden S. Simon, F. Engels ve R. Owen bu çelişkili duruma dikkatleri çekmişlerdi. Rahnema ise (2009: 235) yoksulların bu dönemde iki tür sefalete karşı mücadele etmeye zorlandıklarından bahsetmektedir: bedene zarar veren fiziksel sefalet ve ruhu baştan çıkaran ve sömürgeleştiren törel sefalet.

Çalışma ilişkilerinin büyük bir dönüşüme uğradığı günümüzde ve Gorz'un (2001: 80) deyişiyle ücretli çalışma toplumunun sonuna gelindiği bir dönemde, yoksulların varlığı sistem için artık çok da işlevsel değildir. Bugünün yoksulları (yeni yoksullar), artık sistem içinde yer alan ve emeklerine ihtiyaç duyulan işçiler olarak değil; aksine, bugün daha çok sosyal dışlanma ve sınıf-altı gibi kavramlarla birlikte anılan ve sistemi kökünden değiştirecek bir siyasi devrim tehdidi oluşturmayan bir kitle, suça olan eğilim ve şiddet potansiyelleriyle toplumsal düzene yönelik bir tehdit unsuru olarak görülmektedirler (Balc1, 2007: 15-16).

Yoksullukta meydana gelen bir diğer önemli değişme de, çalışmayla geçim arasındaki doğrusal ilişkinin kopmuş olmasıdır. "Çalışan yoksullar" tabiri de bu dönemde ortaya çıkmıştır. S. Simon sanayileşmenin ilk yıllarında ortaya çıkan bu durumu ilk fark edenlerden biriydi. Ona göre, artık yoksul yok, yoksul işçi vardı. Yoksul artık çalışan bir insan olmuştur. Yoksuldur, ama çalışmak isteyen bir yoksul. Çalıştığı halde yoksul kaldığı için, ahlâk ve iktisat açısından ilgiye değerdir. Yoksuldur, çünkü ya hakkı olan ücreti alamıyordur ya da işsizdir (Meriç, 1999: 139).

Yoksullara yönelik algılarda da önemli değişmeler meydana gelmiştir. Hem dışarıdan yoksullara bakanlar, örneğin yoksullukla mücadele eden kurum ve kuruluşlar, hem de yoksulların kendileri, bugün geçmişten olduğundan oldukça faklı bir yoksulluk algısına sahiptirler. Rahnema'ya göre (2009: 314), yoksullara yardım etmek isteyenler onların durumunu bir hastalık olarak saptadılar. Yoksullukla mücadelenin Dünya Bankası ve Birleşmiş Milletler Kalkınma Programı gibi uluslararası kuruluşlarca çok fazla dillendirilmesinin bir nedeni de bu olsa gerektir. Yine bu bakış açısından kaynaklanıyor olmalı ki, ulusal ve uluslararası politikaların önemli bir kısmı yoksulluk ve yoksullukla mücadele üzerinde yapılmaktadır. Zira günümüz toplumlarında yoksulluğun yönetimi hayati bir mesele halini almıştır. Kısacası, Rahnema'nın (2009: 209) belirttiği gibi, yoksulluk bağlamında, üretim eksenli kapitalist ekonominin ortaya çıkmasıyla geçmişle günümüz arasında toplumsal ve antropolojik bir kopuş meydana gelmiştir.

Yoksulluk gibi modern öncesi dönemde suç da bugün olduğundan çok farklı bir durumdaydı. Geçmiş toplumların çoğu dinsel karakterde olduğu için, suç daha çok "günah" kavramıyla birlikte anılmaktaydı. Suçun tanımlayıcısı ve belirleyicisi hukuk sistemleri değil, çoğunlukla dinsel kurumlardı. Bu yüzden, suçlara verilen cezalar da dinsel kurumların egemenliği altındaydı. Cezalar ise, Foucault'nun (2006: 39-40) belirttiği gibi, ruha yönelik veya özgürlüğü kısıtlayıcı olmaktan ziyade bedene yönelikti ve törensel bir mahiyetteydi. Bu durum, özellikle kiliselerin egemenliği altındaki Ortaçağa Hıristiyan Avrupa'sı için geçerliydi. Kilisenin gücünün zayıflaması oranında modern hukuk sistemleri oluşmaya başlamış, suçların tanımlanmasında ve cezaların uygulanmasında yeni kavrayışlar ve yöntemler ortaya çıkmıştır.

Modern öncesi dönemdeki suçların bir diğer özelliği, örgütlü ve büyük ölçekli olmamalarıydı. O dönemki suçlar daha çok küçük hırsızlıklar ve düzensiz davranışlar düzeyinde ortaya çıkmaktaydı (Marsh, vd., 2006: 11). Aslında, Durkheimcı bakış açısıyla söylemek gerekirse, suç bir sapkınlık türüydü; toplumun genelinin paylaştığı ortak değerleri ve normları ihlal eden veya onlardan sapan suç işlemiş oluyordu. Bu açıdan bakıldığında, toplumda sapkın davranışlarda bulunanlar her zaman olduğuna göre, suçun toplum için kaçınılmaz bir olgu olduğu ortaya çıkmaktadır. Meseleye bu açıdan yaklaşan Durkheim, suçun hem kaçınılmaz hem de gerekli ve faydalı olduğunu ileri sürmüştür (Marsh, vd., 2006: 97).

Suçun sapkın davranışlarla ilişkili bir olgu olarak görülmesi, aslında hangi kesimlerin sapkın davranışlarda bulundukları ve dolayısıyla suç işlediklerini de açığa çıkarmaktadır. Bunlar, toplumun genel ahlâkını bozdukları ve toplumsal normlara önem vermedikleri için belli bir zaman 
toplumdan tecrit edilmeleri (Buğra, 2008: 10) bile düşünülen yoksullardan başkaları değildi. Toplumun gözünde cahil, tembel, hesabını kitabını bilmeyen, kötü alışkanlıklara sahip bu yoksul insanlar en muhtemel sapkın veya suçlulardı. "Tehlikeli sınıflar" tabirinin de yoksullar için kullanıldığı bilinmektedir. Daha sonra bu tehlikeli sınıflar, Marsh ve arkadaşlarının belirttikleri gibi, "suçlu sınıflar" ile birleştirildi. Yeni tehlikeli sınıflar ise yeni doğmakta olan kentli ve sanayi proletaryasıyd. Modern polisin doğuşu da bu tehlikeli sınıflarla ilgiliydi (Marsh, vd., 2006: 11).

Modern dönemde ise suç, ulusal sınırları aşan örgütlü eylemlere dönüştü ve birçok alana konu olan ciddi bir toplumsal sorun haline geldi. Modern dönemde suçlarda hem sayıca hem de çeşitçe bir artış meydan geldi. Ritzer'in (2011: 393) ifade ettiği gibi, günümüzde çok fazla suç var ve bunların çoğu da küresel çağda serbest dolaşıma çıkmıştır. Suçların çeşitliliği ve fazlalığı beraberinde muazzam bir güvenlik sistemini getirmiştir. Ulusal ve uluslararası hukuk sistemleri, alt ve üst düzey mahkemeler, modern hapishaneler, polis ve jandarma teşkilatları ve soruşturma birimleri gibi kurum ve kuruluşlar güvenlik sisteminin birer parçasını oluşturmaktadır.

Modern dönemde suç uluslararası bir boyut kazanmıştır. Bu dönemde yoksullukla bağlantılı suçlar hâlâ görülmekle beraber ve bunlar belki sayıca çok olmalarına rağmen, soykırım ve terörizm gibi uluslararası suçlar daha önemli bulunmaktadır. Çünkü bu tür suçların etkileri ve sonuçları daha yıkıcı olmakta ve daha çok sayıda insanı etkilemektedir. Aynı şekilde, örgütlü ve uluslararası suçlardan olan uyuşturucu, insan kaçakçılığı, dolandırıcılık gibi yüksek maliyetli suçlar, yoksulların yerel düzeyde işlediği düşük maliyetli suçları gölgede bırakmaktadır. İster şiddet suçları isterse mülkiyet suçları olsun, yüksek maliyetli örgütlü suçlar yoksulların güçlerini ve kapasitelerini aşan suçlardır. Yoksulluk, bu tür örgütlü yapılara girmede etkili olabilir; fakat yoksulluğun bütün suç türlerinde tetikleyici bir unsur olarak görülmesi doğru değildir.

Modern dönemde suç ayrıca, dinsel kurumların etkisinden kurtulmuş, resmi hukuk sistemlerinin özel ilgi alanına girmiştir. Buna bağlı olarak suçlara verilen cezalarda da bir değişme meydana gelmiş, Foucault'nun (2006: 39-40) ifade ettiği gibi, bedeni azap ile cezalandırılmaktan vazgeçilmiş ve cezanın bir tören halinde sunulması ortadan kalkmıştır. Modern hukuk sistemlerinde uygulanan cezalar iki zıt kutupta icra edilmektedir. Bir tarafta özgürlüğü kısıtlamaya, bireyi (suçluyu) toplumsal çevreden soyutlamaya yönelik cezalar varken, diğer tarafta sslah edici ve bireyi topluma kazandırmaya yönelik ceza ve uygulamalar vardır.

\section{SUÇ TEORILERİ BAĞLAMINDA YOKSULLUK-SUÇ İIŞSİSİ}

Yoksulluk ve suç, günümüzde birçok disiplinin (sosyoloji, siyaset, iktisat, antropoloji, kültürel çalışmalar) ilgi alanına girmektedir. Dolayısıyla, her iki konuyla ilgili farklı alanlarda birçok kuramsal açıklamaya rastlamak mümkündür. Suçla ilgili özel bir alan (kriminoloji-suç bilimi) oluşmasına rağmen, yoksullukla ilgili özel bir disiplin alanı teşekkül etmemiştir. Bu yüzden, burada sadece yoksullukla ilgili olarak kriminoloji ve aynı zamanda sosyoloji alanlarında mevcut kuramsal açılamalara yer verilecektir. Kriminolojide suç ve suçlulukla ilgili birçok sosyolojik kuramın mevcut olduğunu görmekteyiz. Kuramların çokluğu muhtemelen, Kızmaz'ın da (2005: 150) belirttiği gibi suç olgusunun karmaşıklığından ve suç işleyenlerin farklı profillere sahip olmalarından kaynaklanmaktadır. Burada yalnızca Şikago Okulu, sosyal düzensizlik, gerilim, altkültür, yoksulluk kültürü, etiketleme ve çatışma teorileri gibi yoksullukla suç arasında bağlantı kuran ve kuramsal açıklamalarında işsizlik, yoksulluk, alt sınıf ve alt kültür gibi değişkenlere yer veren teoriler ele alınmaktadır.

\section{1. Şikago Okulu: Doğal Suç Alanları}

Kent sosyologları olarak bilinen ve ekolojik temelde bir kuram geliştiren Şikago Okulu sosyologları, sosyolojik anlamda suçla ilgili ilk önemli çalışmaları ortaya koydular. R. E. Park, L. Wirth, ve E. W. Burgess gibi Şikago Okulu temsilcileri, Siegel'ın belirttiği gibi, yoksulluk gibi çevre koşullarının suç oranlarını nasıl etkilediğini incelediler. Bu kent sosyologları kentsel alanlarda işleyen toplumsal güçlerin bir suç üreten çevre meydana getirdiğini ve bazı çevrelerin suç için "doğal alanlar” olduğunu ileri sürdüler. Onlara göre suç, özellikle yoksulluğun yüksek 


\section{F.Ü. Sosyal Bilimler Dergisi 2015-25/1}

seviyelerde olduğu kentsel alanlarda meydana gelmekteydi. Biyolojik ve psikolojik açıklamalara meydan okuyan bu sosyologlar, suçun kişisel özelliklerin bir sonucu olmadığını, aksine uygun insan ilişkileri ve gelişimi için elverişli olmayan bir çevreye karşı bir tepki olarak ortaya çıktığını iddia ettiler. Onlara göre, suç toplumsal bir olguydu ve ancak toplumsal ve ekonomik koşulların geliştirilmesiyle azaltılabilirdi (Siegel, 2011: 11-12).

Kenti bir laboratuar gibi kullanan bu araştırmacılar, çalışmalarını özellikle alt sınıf kesimlerin ve göçmen grupların yaşadıkları mahallelerde yoğunlaştırdılar. Onlara göre, kötü toplumsal koşullarla toplumsal düzensizliğin hâkim olduğu bu alanlarda yaşayanlar daha fazla suç işleme riskiyle karşı karşıyaydılar (Marsh, vd., 2006: 70). 1920'lerde ve 1930'larda hızla büyüyen ve değişen Şikago şehrini inceleyen Şikago Okulu temsilcileri, sanayileşmiş ve kentleşmiş modern toplumların daha büyük sosyal düzensizlik ve dolayısıyla suç gibi daha büyük sosyal problemleri beraberinde getirdiği görüşünü desteklediler (Marsh, vd., 2006: 99).

Okulun önemli temsilcilerinde Wirth, kentliliği bir yaşam biçimi olarak görürken, bir diğer önemli isim Park, şehrin birçok yönünü (fiziki, ahlâki, siyasi, toplumsal, iktisadi vb.) birlikte ele almıştır. Göçmen işçilerin ve bazı etnik grupların yaşadığı kolonilere ve gettolara dikkat çeken Park, şehrin ırki, mesleki ve kültürel açılardan ayrışmaya uğradığını öne sürmüş ve sınırlanmış alanlarda oluşan "sefahat mahalleleri"nden söz etmiştir (Tuna, 2013: 60-62). Kentte oluşan "doğal" birimleri bir rekabet ve çatışma ortamının sonucu olarak gören Park, kentin doğal ve değişmeyen güçlerin etkisiyle meydana geldiğini belirtmekte ve kentleri insan doğasının bir ürünü olarak ele almaktadır. Bu yüzden ona göre, kentte oluşan çöküntü alanları ve gettoları kaldırmak, insanın içgüdülerini yok etmek anlamına gelmektedir (Aslanoğlu, 2000: 26-28).

Görüldüğü üzere Şikago Okulu, hızlı ve artan bir şekilde büyüyen ve değişen kentlere ve bu kentlerdeki düzensizliklere, geçişlere, yerleşme biçimlerine, etnik ve göçmen gruplara ve alt sınıf mahallelere yoğunlaşmıştır. Okulun temsilcileri, suçun ortaya çıktığı yoksul mahalleleri, doğal suç alanları olarak görmüşlerdir. Bunların kırsal yoksulluk ve kırsal alanlarda meydana gelen suçlar ile "beyaz yakalı suçlar" olarak görülen üst sınıflara ait suçları incelemedikleri ya da ihmal ettikleri anlaşılmaktadır. Dolayısıyla, Okulun suçla ilgili açıklamaları kentlerin çöküntü alanları ve gettolarında görülen yoksullukla sınırlı kaldığı görülmektedir. Bu da gösteriyor ki, bu Okulun açıklamaları yoksulluk-suç ilişkisini bir bütün olarak açıklamada yetersiz kalmaktadır.

\subsection{Sosyal Düzensizlik Kuramı: Sosyal Çözülme ve Suç}

Sosyal düzensizlik (organizasyonluk) kuramı, Şikago Okulunun görüşlerini temel alarak Shaw ve McKay tarafından geliştirilen bir kuramdır. Kentleri sosyal çözülmenin en fazla görüldügü yerler olarak ele alan sosyal düzensizlik teorisyenleri, bu yüzden çalışmalarını suç eylemlerinin en çok görüldüğü getto gibi çözülmüş alanlarda yoğunlaştırmışlardır. Onlara göre, bu alanlarda sosyal çözülmeye en çok etki eden unsurlar ise, başta yoksulluk olmak üzere, kültürel çeşitlilik ve fiziksel hareketlilik gibi kent yaşamını karakterize eden faktörlerdir (Kızmaz, 2005: 151-152).

Bu kuramda, anlaşıldığı kadarıyla yoksulluğun suça doğrudan değil, dolaylı bir etkisi söz konusudur. Yoksulluk ve kültürel heterojenlik gibi faktörler kentlerde sosyal çözülmeye yol açmakta, bu da bireylerin toplumsal değerlere olan bağlılıklarını zayıflatmakta ve onları suç işlemeye yöneltmektedir (Kızmaz, 2006a: 12). Kuramın son dönem temsilcilerinden Sampson ve Groves ise sosyal çözülmenin suç işlemede etkili olan göstergeleri olarak a) yerleşim bölgelerinin düşük ekonomik düzeyi, b) farklı etnik grupların aynı yerleşim yerini paylaşmaları, c) yerleşim yerlerinin aşırı hareketliliği, d) ailenin parçalanması ve işlevlerini yitirmesi ve e) kentleşmeyi göstermektedirler (Kızmaz, 2006a: 13). Ayrıca, Bohm'un belirttiği gibi, sosyal denetimin zayıflığı, suçlu davranışın aile ve toplumsal çevre tarafindan onay görmesi, suç işleme fırsatlarının olması ve meşru iş ve eğitim için yeterli firsatın olmaması gibi unsurlar da suç işlemede etkili olmaktadır (Ak. Kızmaz, 2006a: 13).

Sosyal düzensizlik kuramının suçu toplumsal bir olgu olarak ele aldığı ve onu yoksulluk, işsizlik, denetim yokluğu ve aile parçalanması gibi toplumsal sorunlarla ilişkilendirdiği 
görülmektedir. Bu kuramda da yoksulluğun suça etki eden faktörlerden biri olarak ele alındığı açıktır. Ancak bu ilişkinin ne kadar net ve doğrusal olduğu açık değildir. Kurama yönelik eleştirilerden biri, sosyal organizasyonluğu sadece yoksul bölgelerle sınırlandırması, muhtemel diğer organizasyonluk biçimlerini ve dolayısıyla suç işleme türlerini ihmal etmiş olmasıdır (Kizmaz, 2005: 152).

\subsection{Gerilim Kuramı: Amaç-Araç Uyuşmazlığı ve Suç}

Gerilim kuramı ile alt-kültür kuramları, yapısal-işlevselci kuram kapsamında değerlendirmek mümkündür. Gerilim kuramının en önemli temsilcisi Merton, aynı zamanda işlevselci kuramın da önde gelen kuramcılarından biridir. İşlevselci kurama göre, Giddens'ın (2008: 844) belirttiği gibi, suç ve sapkınlık yapısal gerilimlerden ve ahlâki düzenleme yokluğundan kaynaklanmaktadır. Gerilim kuramları, belirli gerilimlerin suç ihtimalini arttırdığını ifade ederler. Örneğin, maddi başarı veya statü gibi hedeflere ulaşmada yeteneksizlik, olumlu bir durumun ortadan kalkması (örneğin bir arkadaşın ölümü veya değerli mülkiyetlerin kaybı) veya olumsuz bir durumun ortaya çıkması (fiziksel sakatlık gibi) vb. durumlar gerilimlere yol açabilir. Bu tür gerilimleri yaşayan bireyler hayal kırıklığına uğrarlar ve bu durumla başa çıkmak için suça bulaşabilirler. Bu durumda suç, gerilimleri azaltmanın veya onlardan kaçmanın bir yolu olabilir (Agnew, 2009: 332).

Gerilim teorisi kuramcıları, suçu alt sınıflar arasındaki hayal kırıklığı ve kızgınlığın doğrudan bir sonucu olarak görürler (Siegel, 2011: 174). Kuramın en önemli ismi Merton, ne tür toplumsal koşul ve durumların bazı insanları kuralları ihlal etmeye ve suçlu veya sapkın davranmaya ittiğini incelemiştir (Marsh, vd., 2006: 101). Metron, Amerikan toplumu örneğinde, toplumda maddi başarı gibi kültürel amaçların çok fazla yüceltildiğini, fakat bu amaçlara erişim yollarının çok fazla belli olmadığını, belli olsa bile fazla önemsenmediğini belirtmektedir. Bu durumda, toplumca önceden belirlenmiş standartlar (kurumlaşmış araçlar) ile kültürel amaçlara ulaşma arasında bir gerilim ortaya çıkmaktadır. Haliyle bu gerilimden en çok etkilenenler toplumsal firsatlardan en az yararlananlar olacaktır (alt sinıflar). Bu yüzden Merton, Giddens'ın (2008: 846) ifade ettiği gibi, yükselen hedeflerle kalıcı eşitsizlikler arasındaki karşıtlığı vurgular ve sapkın davranışın önemli bir bileşeni olarak göreli yoksullaşmayı gösterir. Ancak, yoksullar bu gerilimden kurtulmak veya gerilimi hafifletmek için "hırsızlık ve uyuşturucu kaçakçılığı gibi sapkın yöntemler aracıllğıyla amaçlarına ulaşabilirler veya toplumca kabul edilen amaçları reddedip yerlerine sert ve saldırgan olma gibi sapkın hedefleri geçirebilirler" (Siegel, 2011: 174).

Kısacası Merton, Amerikan toplumunda alt sinıflara mensup bireylerin yasal yollar aracılığıyla meşru amaçlara ulaşma imkânlarının engellendiğini ileri sürmektedir (Agnew, 2009: 332). Bunun anlamı, üst sinıflarda yer alanlarla eşit imkânlara ve firsatlara sahip olmayan alt sinıftakilerin amaçlarına ulaşmak için gayrimeşru yollara başvurmak zorunda kaldıklarıdır. Yapısal gerilime vurgu yapan Merton, bu yüzden suçun nedenlerinin toplumsal yapıda aranması gerektiğini belirtmektedir (Kızmaz, 2005: 154).

Görüldüğü üzere gerilim kuramı, özellikle Merton, suçu alt sınıflara ait bir olgu olarak görmüş, suçun temel nedeni olarak da yoksulluğu göstermiştir. Kuram suç ve suçluluğa ilişkin önemli açılamalar getirmesine rağmen, birçok faktörü ihmal ettiği veya bazı faktörler arasında ilişki kurmada başarısız olduğu için yoğun bir şekilde eleştirilmiştir. Her şeyden önce kuram, Agnew'in (2009: 332) belirttiği gibi, 1930'larda Büyük Depresyonun ortasında geliştirildiği için, kuramda sınıf geriliminin aşırı vurgulanması şaşırtıcı değildir. Bununla birlikte, kuramın alt sınıf suçlara yoğunlaşıp üst sınıflara ait suçları (beyaz yakalı suçlar) ihmal etmesi büyük bir eksiklik olarak görülmektedir. Zira, Kızmaz'ın da (2005: 157) vurguladığı gibi, suç sadece alt sınıflara ait bir olgu değildir, elitler ve üst sınıf bireyleri arasında da suç oranları yüksektir.

Alt sınıfların yoksulluk gerçeği bir yana, bütün yoksulların benzer gerilimlerden ne oranda etkilendikleri, gerilimlere nasıl tepki verdikleri ve suç dışında ne tür çarelere başvurdukları gibi sorulara gerilim kuramları kapsamında net cevaplar vermek mümkün gözükmemektedir. Bir kere faklı toplumların alt sinıflarında yer alan yoksulların farklı kültürel değerlere sahip olmaları ve 


\section{F.Ü. Sosyal Bilimler Dergisi 2015-25/1}

yoksullar arasındaki bireysel farklılıklar, yoksulluk-suç ilişkisini genel bir kuramla açıklamay1 zorlaştırmaktadır. Ayrıca, toplumun genel yapısı içinde eşit firsatlardan mahrum olan yoksulları, bir de sapkın davranışlarla etiketletmek veya suça meyilli kişilikler olarak göstermek, kurbanı suçlamanın ötesinde bir anlam taşımamaktadır.

\subsection{Alt-kültür Kuramları: İşçi sınıfı Gençlik Suçları}

Gerilim kuramları gibi alt-kültür kuramları da alt sınıfların- özellikle işçi sınıfına mensup gençlik çetelerinin- suçluluğuyla ilgilenirler. Kuramın önemli temsilcilerinden A. Cohen, Merton gibi, suçun nedeni olarak Amerikan toplumundaki çelişkileri görmüştür. "Suçlu Çocuklar" adlı eserinde Cohen, işçi sınıfının alt tabakalarından gelen ve konumlarından rahatsız olan erkek çocukların çeteler gibi suç alt-kültürlerine katıldıklarını ileri sürer. Ona göre, bu gençler orta sınıf değerlerini yadsırlar, bunların yerine suçluluk ve diğer bazı uyumsuzluklar gibi karşı çıkmayı kutsayan normlar geliştirirler (Giddens, 2008: 846).

Cohen ve diğer alt-kültür kuramcıları, suçlu davranışın alt-kültürün kollektif gerçekliğinde temellendiğini iddia ederler ve kriminologların alt-kültürü tanımlayan özel kültürel dinamikleri (konuşma ve davranma biçimi, giyim tarzı, ortak duygular, ortak sorunlar) araştırmaları gerektiğini söylerler. Ayrıca, onlara göre, alt-kültür suçluluğunun gerçekleşme biçimlerinin alt-kültür üyelerinin ortak sorunlarına genel bir çözüm getirip getirmediği de araştırılmalıdır (Ferrell, 2009: 225).

Alt-kültürü daha büyük toplum içindeki belirli bir sosyal sınıfa veya gruba özgü bir dizi değerler, inançlar ve gelenekler olarak tanımlayan Siegel (2011: 142), alt-kültürlerin çoğunlukla geleneksel toplumsal normlarla çatıştığını belirtmektedir. Ona göre bu alt kültürler kendilerine özgü değerleri ve inançları sürdürme eğilimindedirler. Siegel'a göre suçlu davranış, geleneksel topluma karşı bir isyanın değil, alt sınıftakilerin alt-kültürlere uyumunun bir ifadesidir. Siegel ayrıca, alt-kültürel değerlerin kültürel geçiş olarak adlandırılan bir süreçle kuşaktan kuşağa geçtiğini de vurgulamaktadır. Ancak, burada şunu önemle belirtmek gerekir ki, bu bütün altkültürlerin toplumun geleneksel normlarıyla veya genel kültürüyle çatıştı̆̆ 1 ve bu yüzden de suçlu davranışlara yol açtığı anlamına gelmemektedir. Burada söz konusu olan, daha çok işçi sınıfına mensup gençlerin oluşturmuş oldukları suçlu alt-kültürlerdir. Suçlu davranış da bu alt-kültürlere uyumun bir tezahürü olarak görülmektedir.

Bir diğer alt-kültür kuramcısı Miller, işçi sınıfı kültürünün (onun deyişiyle alt sınıf kültürü), belirli "temel ilgiler" (focal concerns) tarafından nitelendirildiğini ve bu ilgilerin (sertlik, açgözlülük-smartness, heyecan gibi) saldırganlığı ve çoğunlukla da suçlu davranış1 cesaretlendirdiğini öne sürmektedir. Bu yüzden, orta sınıftan ziyade işçi sınıfına mensup olmak, bireyleri işçi sınıfı hayat tarzına bir tepki türü olarak görülen suçlu alt-kültürle suçluluğa yatkın hale getirmektedir (Marsh, vd., 2006: 106; Siegel, 2011: 157). Bu temel ilgi veya endişeler (sıkınt1, sertlik, açgözlülük, heyecan, kader, özerklik), illegal veya şiddet eylemlerini tetikler (Siegel, 2011: 157). Kısacası Miller, diğer alt-kültür kuramcılarının iddia ettikleri gibi, çocuk suçluluğunun orta sınıfa özgü değer sistemine bir tepki olarak ortaya çıkmadığını, aksine alt sınıfın değerler sisteminde suçluluğa ait kültürel unsurların zaten bulunduğunu ileri sürmektedir (Kızmaz, 2005: 160).

Cloward ve Ohlin ise, başarıya ulaşmanın farklı "gayrimeşru yolları"nı göz önünde bulundururlar ve potansiyel suçluluğun üç farklı alt-kültür tipinden birine katılmaya bir tepki olabileceğini iddia etmektedirler. Bu alt-kültürler şunlardır: suç alt-kültürü, çatışma alt-kültürü, hayalperest alt-kültür (Marsh, vd., 2006: 106). "Ayırıcı fırsatlar" teorisini geliştiren Cloward ve Ohlin, ekonomik isteklerinin engellenmiş olmasının bireylerde düşük bir benlik algısı ve engelleme hissini meydana getirdiğini, bunun da özgül çete ortamlarında suçluluğa yol açtığını belirtmektedirler (K1zmaz, 2005: 159).

Alt-kültür kuramlarının yoksullukla ilişkili suçlardan ziyade, işçi sınıfı suçluluğuna- özellikle çocuk ve genç suçluluğuna- yoğunlaştığı görülmektedir. İşçi sınıfına mensup gençlik gruplarının 
geliştirmiş oldukları alt-kültürel değerlerin suçluluğun meydana gelmesinde etkili olduğu varsayılmıştır. Anlaşıldığı kadarıyla alt-kültürel kuramların doğrudan değil, dolaylı olarak yoksullukla ilişkisi bulunmaktadır. Zira çoğunlukla alt sınıfta gösterilen işçi sınıfını çalışan yoksullar kapsamında değerlendirmek mümkündür. Yoksul kesimlerle işçi sınıfının birtakım ortak kültürel değerleri paylaştıkları hesaba katıldığında, işçi sınıfı alt-kültürü olarak bahsedilen olgunun aslında yoksulluk alt-kültürüyle ne kadar benzeştiği de ortaya çıkmaktadır. Dolayısıyla, suçla ilgili alt-kültür kuram açıklamalarının yoksulluğu da kısmen içerdiğini söylemek mümkündür.

\subsection{Yoksulluk Kültürü: Bir Alt-kültür Örneği}

Yoksulluk kültürü, O. Lewis'in çalışmalarında geliştirilen bir kavramdır. Lewis (1959: 1-2), azgelişmiş ülkelerin çoğunun coğrafyası, tarihi, ekonomisi siyaseti ve hatta gelenekleri hakkında çok bilgi sahibi olduğumuzu; fakat insanlarının- özellikle alt sınıfta yer alan insanlarınınpsikolojisi hakkında, onların nasıl düşündükleri ve hissettikleri, ne için endişelendikleri, neyi tartıştıkları, neye katıldıkları ve neden zevk aldıkları hakkında çok az şey bildiğimizi söylemektedir. Yoksulluğu daha büyük ulusal kültürdeki katılımı etkileyen dinamik bir faktör olarak ele alan Lewis, yoksulluğun kendi alt-kültürünü oluşturduğunu, dolayısıyla bir yoksulluk alt-kültüründen söz etmenin mümkün olduğunu belirtmektedir. "Bana öyle görünüyor ki, yoksulluk kültürü bölgesel, kentsel-kırsal ve hatta ulusal sınırları aşmaktadır." Lewis ayrıca, yoksulluk kültürünü anlamak için yoksullarla birlikte yaşamak, onların dilini, geleneklerini, sorunlarını ve isteklerini tanımak gerektiğini ifade etmektedir.

Lewis, alt sınıf alanlardaki zor yaşam biçiminin, temel özellikleri sorumsuzluk, ilgisizlik, çaresizlik ile okul, devlet kurumları ve polis gibi toplumsal kurumlara güvensizlik olan ve kuşaktan kuşağa geçen bir yoksulluk kültürünü meydana getirdiğini iddia etmektedir (Siegel, 2011: 137). Lewis, yoksulluk kültürünü yoksulluğu kuşatan ve aile bağları vasıtasıyla kuşaktan kuşağa geçen birbirleriyle ilişkili toplumsal, ekonomik ve kültürel davranışları ve özellikleri tarif etmek için kullandı. Bu özellikler şunlardır: geleceğini düşünmemek, gizlilikten yoksun kalabalık yaşam alanları, dedikoduculuk, alkolizm, ailede ve komşular arasında şiddetli kavgalar, genç yaşta cinsel aktiviteye eğilim, içgüdüsel ve tepkisel birlikler ve sıklıkla anne ve çocukları terk etme (Fuchs, 2005: 15).

Lewis, yoksulluk kültürünün yoksulları toplumun geri kalan kesiminden ayırmakla kalmadığını, aynı zamanda onları yoksulluğa mahkûm ettiğini de savunmaktadır. Lewis'e göre, karşılaştıkları sorunları, engelleri ve dışlanmışlıkları yenmek için yoksullar, kendilerine özgü tutumlar, değerler ve davranışlar geliştirerek kendilerine göre bir hayat tarzı meydana getirmişler ve buna uyum sağlamışlardır. Bu alt kültürün en temel özelliği ise toplumsal örgütlenme yokluğudur (Slattery, 2008: 390-391).

Yoksulluk kültürü çalışmalarında ön plana çıkan kavramlardan biri de suçtur. Özellikle işsizlik, mesleki becerilerden yoksunluk gibi faktörler, yoksulları hırsızlık, şiddet, uyuşturucu satışı ve cinsel suçlar gibi suçlara itmektedir. Aile içinde ise daha çok şiddet içerikli davranışlar yaygındır. Aile içi sorunların çözümünde şiddete başvurma, çocukları dövme, kadınlara şiddet uygulama, komşularla olan anlaşmazlıklarda şiddet kullanma vb. eylemlere sık rastlanılmaktadır.

Lewis'in yoksulluk kültürü tezi, çoğunlukla "kurbanı suçlama" tarzında algılanmış; bu yüzden de sert eleştirilere uğramıştır. Örneğin Bayat, Lewis'in yoksulluk kültürü kavramıyla farkında olmadan "edilgin yoksul" fikrini yaygınlaştırdığını ve "marjinal insan"1 kültürel bir tip olarak tanımlamakla hükümetlerin işini kolaylaştırdığını belirtmektedir. Uzun yıllar baskın bakış açısı olarak kalan yoksulluk kültürü, Bayat'a göre, hem Amerika'da yoksulluk-karşitı söylemi ve politikayı hem de Üçüncü Dünya seçkinlerinin yoksullara yönelik algılarını belirlemiştir. Bayat'a göre, Lewis'in yoksulluk kültürünü genellemesi, farklı kültürlerde yoksulların yoksullukla baş ettikleri farklı yolları göz ardı etmesine neden olmuştur (Bayat, 2006: 34-35).

Lewis'in yoksulluk kültürünü bütün kültürlerdeki yoksullara genellediği yönündeki iddia doğru değildir. Çünkü Lewis, gelişmiş ülkelerdeki yoksulları değil, Latin Amerika örneğinde 


\section{F.Ü. Sosyal Bilimler Dergisi 2015-25/1}

(Meksika, Porto Riko gibi), gelişmekte olan ülkelerdeki yoksulları incelemiştir. Yoksulluk kültürünün bütün toplumlarda benzer şekillerde görüldüğünü ve ortak özellikler sergilediğini iddia etmek belki doğru değildir; fakat hemen her toplumda bazı yoksullar arasında yoksulluk kültürüne benzer yaşam koşullarının var olduğunu söylemek mümkündür. Örneğin, Lewis'in yoksulluk kültürü tezinden hareketle Türkiye gecekondularında incelemeler yapan Türkdoğan (2006 ), bir yoksulluk alt-kültürüne ait birtakım değer ve normların varlığını gösteren bulgulara ulaşmıştır. Türkdoğan ayrıca, yoksulluğun ortadan kalkması durumunda bile, kendine özgü değer ve normlarıyla yoksulluk alt-kültürün uzun yıllar varlığını sürdürebileceğini belirtmektedir.

Suçla ilgili olarak yoksulluk kültürü tezine yöneltilebilecek en önemli eleştirilerden biri şudur: Benzer yaşam koşullarında yaşayan yoksullardan neden bazıları suç türü eylemlere katılmakta, ama geriye kalan büyük çoğunluk katılmamaktadır? Burada kültür, toplumsal denetim ve bireysel farklılıklar gibi unsurların belirleyici olduğu anlaşılmaktadır. Sonuç olarak, Lewis'in ana vurgusunun yoksulluk-suç ilişkisi üzerinde olmadığı görülmekte, yoksulluk kültürünün de yoksulların karşılaştıkları sorunlara çözüm bulmak için başvurdukları yollardan hareketle meydana getirdikleri ve kendine özgü birtakım değerleri ve normları olan bir uyum stratejisi olduğu anlaşılmaktadır.

\subsection{Etiketleme Kuramı: Damga ve Suç}

Etiketleme (damgalama) kuramı etkileşimci kuram içinde yer alan bir kuramdır. Etiketleme kuramı, etkileşimci kuramın suç ve sapmayla ilgili temel öğesini oluşturmaktadır (Marsh, vd., 2006: 106). Giddens, kuramın sapkınlığı sapkınlar ile sapkın olmayanlar arasındaki bir etkileşim süresi olarak gördüğünü belirtmektedir. Temel soru şudur: neden bazı insanlara sapkın etiketi yapıştırılır? Cevap büyük ölçüde toplumsal güçle ilgilidir. Zengin-yoksul, erkek-kadın, yaşlı-genç, çoğunluk-azınlık gibi ayrımlar söz konusu olduğunda, kuralları güçlüler belirler. Zengin mahalledeki bir çocuğun hırsızlığı ile yoksul mahalledeki bir çocuğun hırsızlığı farklı şekillerde yorumlanır. Birincisine "masum çocuk oyunları", ikincisine ise "çocuk yaştaki hırsılzlı eğilimleri" olarak bakilır (Giddens, 2008: 848).

$\mathrm{Bu}$ kurama göre, suçun tanımı toplumsal gücü elinde tutan insanların tercihlerini ve görüşlerini yansıtır. Bu insanlar kendi doğru ve yanlış tanımlamalarını nüfusun geri kalanına empoze etmek için nüfuzlarını kullanırlar. İnsanları etiketleyerek güçlerini sürdürürler. Bu yüzden suçlular, toplumsal kuralları ihlal ettikleri için toplumun serseriler (outcats) veya sapkınlar olarak etiketlediği bireylerdir (Siegel, 2011: 17). Kuramı en iyi şekilde kuramın kendisiyle özdeşleştiği Becker'ın şu ifadesi özetlemektedir: "sapkın, etiketin başarılı bir şekilde uygulandığı biridir; sapkın davranış insanların öyle etiketlediği davranıştır" (Becker, 1966: 9).

Becker, sapkın kimliklerin etiketleme yoluyla oluşturulduğunu iddia etmektedir (Giddens, 2008: 848). Bu yüzden, etiketleme teorisyenleri suç veya sapmanın tam resminin sadece suçluların ve onların özelliklerinin incelenmesiyle elde edilemeyeceğini savunurlar. Onlara göre, resmin bütününü görmek için kurallara uymayanlara yönelik toplumsal tepkilerin de açığa çıkarılması gerekmektedir (Maddan ve Marshall, 2009: 253). Kurama göre toplumsal etkileşim sürecinde damgalanan birey, giderek toplumdan dişlanmakta ve suçlu gruplarla temasa geçmektedir. $\mathrm{Bu}$ şekilde bireyler damgalandıkları davranışı giderek daha fazla yapma eğilimi gösterirler (Kızmaz, 2006a: 26-27; 2005: 167).

Kuramın bir diğer temsilcisi Lemert ise, birincil ve ikincil sapkınlık türlerinden söz etmektedir. Lemert'e göre ara sira ihlal edilen trafik kuralları, peşinden bir etiketleme getirmediğinden olağanlaştırılır. Bu ve küçük hırsızlıklar gibi eylemler göz ardı edilir. Bunlar birincil sapkınlıktır. Ancak, bazı durumlarda olağanlaştırma kabul edilmez ve kişi suçlu ya da kabahatli diye damgalanır. Bireyin etiketi kabullendiği ve kendisini sapkın olarak görmeye başladığı durumlar ikincil sapkınlıktır (Giddens, 2008: 848).

Burada şunu da belirtmek gerekir ki, etiketleme kuramında sapma ve sapkınlık sabit değişkenler değil, zamanla değişen bileşenlerdir. Becker, değişimi etkileyen unsurları şöyle 
açıklamaktadır. Birincisi, daha önceki zamanlarda sapkın etiketi yapıştırılan birey tipinin zamanla değişmesidir. Örneğin, Ortaçağ'da dilencilikten dolayı sapkın olarak görülen ve tutuklanan bireyler bugün sapkın olarak görülmüyor ve tutuklanmıyorlar. İkincisi, sapkınlığın derecesiyle ilgilidir. Kimin sapkın olarak görüleceği, eylemi işleyenin ve kurbanın kim olduğuna bağlıdır. Beyaz yakalı suçlular ile sokak köşesi suçlularının resmi makamlarca farklı muamele görmeleri buna örnek gösterilebilir. Üçüncüsü, dışarıdaki teriminin farklı bireyler için kullanılmasıdır. Dışarıdakiler terimi kurallara uymayan bireyler tarafindan kuralları yapan kişilere de uygulanabilir. Becker, buradan hareketle dört sapkın tipi belirler: sahte suçlu, uyumlu kimse, saf sapkın ve gizli sapkın (Maddan ve Marshall, 2009: 255).

Diğer kuramlar gibi etiketleme kuramı da ciddi eleştiriler almıştır. Eleştirilerin başında kuramın sapkın eylemlerin kaynaklarını ihmal ettiği eleştirisi gelmektedir. Kurama ayrıca, kuramın belli başlı suç çeşidine yoğunlaştığı ve diğer suç türlerini görmezden geldiği, adalet ve hukuk sisteminin gücünü çok abarttığı, suç işleyenler lehine bir gerekçe oluşturduğu, etiketlemenin sonuçlarına ilişkin öngördüğü davranışın kaçınılmaz olmadığı, damgalamanın bireyi suça ittiği varsayımının basit bir yaklaşım olduğu gibi eleştiriler de getirilmiştir (Kızmaz, 2005: 169).

Etiketleme kuramının, kurbanı suçlama tarzında bir yaklaşımı benimsemediği anlaşılmaktadır. Sapkın etiketi çoğunlukla toplumsal gücü ellerinde bulunduranlar tarafindan verildiği için, bu etiketi en çok alanlar muhtemelen başta yoksullar olmak üzere alt sınıflarda yer alanlardır. Belli bir davranıştan ötürü sapkın etiketiyle damgalanan kişinin, etiketten dolayı o sapkın davranış1 tekrarlamaya devam ettiği iddiası, kişinin pasif durumda kaldığını ve başka türlü davranmasının mümkün olmadığını ima etmektedir. Dolayısıyla sapkınlık ve suç, etiketin yapıştırıldığı bireylerin kaderi olmaktadır. Bu da, eğer damgalananlar yoksullarsa, sapkınlık ve suçun yoksulların yaşam tarzlarının bir parçası olduğu anlamına gelmektedir.

\section{7. Çatışma Kuramları: Kapitalizm, Sınıf/Çıkar Çatışması ve Suç}

$\mathrm{Bu}$ ad altında bir dizi yaklaşım bulunmaktadır: eleştirel kriminoloji, radikal kriminoloji, sol realizm ve sol idealizm (Marsh, vd., 2006: 119). Marksist teoriden yararlanan çatışma kuramları, önceki açıklamaları reddederler (Taylor, Walton, Young). Bunlar, bireylerin kapitalist sistemin eşitsizliklerine bir tepki olarak sapkın davranışlar sergilediklerini öne sürmektedirler. Ayrıca, yeni (eleştirel) kriminolojideki çalışmalar, suçun toplumun her düzeyinde işlendiğini ve toplumsal gruplar arasındaki eşitsizliklerle rakip çıkarlar bağlamında anlaşılması gerektiğini vurgularlar (Giddens, 2008: 851-852).

Marksist perspektiften suç, büyük ölçüde kapitalizmin ürünüdür. Kapitalist toplumlardaki nispeten yüksek suç oranları, böyle bir sistemin doğasında var olan çelişkilerin ve sorunların bir göstergesidir. 1970'lerde çatışma kuramlarının önde gelen temsilcilerinden biri olan Qinney, suç ve ceza hukukunu anlamak için kapitalist toplumun neo-Marksist bir yorumunu yapar ve kapitalizmin temel yönlerinin (yabancılaşma, eşitsizlik, yoksulluk ve kapitalist devletin ekonomik krizi) incelenmesi gerektiğini belirtir. Durkheim'ın suçun gerekli ve kaçınılmaz olduğu yönündeki görüşüne karşı çıkan Quinney, "suç kapitalizmin çelişkilerinden kaynaklanmakta ve bu çelişkilere daha fazla katkıda bulunmaktadır" demektedir (Marsh, vd., 2006: 120; Friedrichs, 2009: 212). Quinney, suçları iki gruba ayırmaktadır: 1) kapitalist sınıf tarafından gerçekleştirilen tahakküm ve baskıya dayalı suçlar, 2) işçiler ve sıradan insanlar tarafından işlenen uyum ve karşı koyma suçları. Buradan hareketle Quinney, kapitalizmin gelişimiyle birlikte suçluluğun nasıl bir anlam ve boyut kazandığı sorunu üzerinde durmuştur (Kızmaz, 2006b: 310).

Çatışmacı teorisyenler, hukukun toplumun huzurunu sürdürmek içim tasarlandığı ve suçluların diğerlerinin haklarını çiğnemek isteyen kötü niyetli kişiler olduğu görüşünü reddederler. Onlara göre, dünya sayısız sayıda insanın hayatına zarar veren ve milyonlarca dolar maliyeti olan eylem ve davranışlarla doludur- 1rkçılık, cinsiyet ayrımı, emperyalizm, çevrenin tahribi ve işçilerin sömürüsü gibi. Fakat bu davranışlar "gerçek suçlar" olarak görülmezler; çünkü onlar hukukun özünü kontrol eden ve kendilerini ondan muaf tutan zengin ve güçlülerin eylemleridir. Genellikle hafif cezalar 


\section{F.Ü. Sosyal Bilimler Dergisi 2015-25/1}

alan bunlar (zengin beyaz-yakalı suçlular), aslında en sert yaptırımları hak etmektedirler. Oysa en sert cezalar, hırsızlık gibi birkaç dolarlık maliyetli suçları işleyen ve politik-toplumsal güçleri olmayan kişilere uygulanır; çünkü bu suçlar toplumun refahına yönelik bir tehdit olarak görülmektedir (Siegel, 2011: 198).

Görüldüğü üzere çatışma kuramları, suç analizini daha makro boyutta, kapitalist sistemle ve toplumsal yapıyla ilişkili olarak ele almaktadırlar. Suçlu davranışlarda bulunan kişilerin özelliklerini betimlemekten ziyade, toplumsal güç, baskı ve çıkar çatışması üzerinde yoğunlaşırlar. Yoksulluğu, eşitsizliği, sömürüyü, baskıyı ve bunlara bağlı olarak ortaya çıkan suç eylemlerini, doğrudan kapitalist sistemin bir sonucu olarak görmektedirler. Alt sınıfta yer alan kişilerin işledikleri suçlardan ziyade üst sınıfta yer alan kişilerin işledikleri suçları (beyaz-yakalı suçları) daha önemli bulmaktadırlar. Çünkü onlara göre, bu suçların etkisi hem daha fazladır hem de bu suçlar daha yüksek maliyetlidir. Örneğin, örgütlü suçlardan bahseden Pearce, Amerika'daki şirketlerin suç eylemlerinin geleneksel suçların içerdiğinden çok daha fazla maliyet içerdiğini savunmaktadır (Marsh, vd., 2006: 121). Bunlar ayrıca (sol realizm), suç dörtlüsü (square of crime) olarak tanımladığı suçun dört bileşeni (devlet, toplum, suçlular ve kurbanlar) olduğunu söyler ve suçun bütün biçimlerinin analizine bunların hepsinin dâhil edilmesi gerektiğini belirtirler (Marsh, vd., 2006: 123). Bununla birlikte, çatışmacı kuramların kültürel kalıplar, bireysel farklılıklar ve suça eğilim gibi unsurları ihmal ettikleri görülmektedir. Suçun küreselleştiği dünyada örgütlü ve beyaz yakalı suçlar daha önemli görünebilir; fakat bu, bütün suçların sınıf veya çıkar çatışmaları ya da güç ilişkilerinin sonucu olarak ortay çıktığı ve bu ilişkiler dışında suç eylemlerinin meydana gelmediği anlamına gelmemektedir.

\section{SONUÇ}

Yoksulluğun suçla olan ilişkisi, görüldügü üzere, suçla ilgili birçok kuramda merkezi bir yer teşkil etmektedir. Birçok kuramda yoksulluk, suça yol açan en önemli toplumsal faktör olarak görülmüş, yoksulların yaşadığı toplumsal mekânlar (kentsel gecekondu ve çöküntü alanları)Şikago Okulunda olduğu gibi- doğal suç alanları olarak kabul edilmiş, yoksullar bir nevi potansiyel suçlular olarak resmedilmiştir. Bazı kuramlar (Şikago Okulu, gerilim kuramı, sosyal düzensizlik kuramı, alt-kültür kuramlar) dikkatlerini yoksul ve işçi sınıfı suçları üzerine yoğunlaştırırken, diğer kuramlar ise (etiketleme kuramı ve çatışma kuramları) sınıf yapısı, baskı, güç ilişkileri ve çıkar çatışmasına dikkat çekmişlerdir. Birçok suç kuramında dikkatlerin yoksulluk üzerinde yoğunlaşması, muhtemelen suçun yoksullukla olan yakın ilişkisinden ileri gelmektedir. Kuramların çoğunda kentsel alanlardaki yüksek yoksulluk seviyeleriyle suç oranları arasında nedensel bir ilişkinin var olduğu varsayılmıştır (Lee, 2000: 189). Bu, hem yoksulların hem de yoksul yerleşim alanlarının taşıdıkları birtakım özelliklerinden dolayı, diğer kesimlere ve yerleşimlere nazaran, suça daha meyilli oldukları anlamına gelmektedir. Amerika gibi toplumlarda işçi sınıfına mensup gençlik alt-kültürlerinde suça bulaşma eğiliminin fazla olması ve yoksulluğun yoğun yaşandığı bazı yerlerde suç oranlarının yüksek olması, bu varsayımı destekler niteliktedir. Ancak, bu durumu bütün kültürlere ve yoksul kesimlere genellemek mümkün değildir. Suçla yoksulluk arasındaki ilişkinin önemli bir özelliği, bu ilişkinin kültürlere ve toplumsal kesimlere göre farklılık göstermesidir.

Suçu, sonucunda devlet otoritesi, toplumsal damga ve statü kaybı gibi yaptırımlara uğrayan "toplumsal davranış kurallarının bir ihlali” (Siegel, 2011: 17) olarak ele alırsak, başta yoksullar olmak üzere, alt sınıf kesimlerin bu kuralları çokça ihlal ettikleri bir gerçektir. Suç kuramlarının çoğunun da bu toplumsal davranış kurallarını dikkate aldıkları ve dolayısıyla alt sınıf kesimlerdeki kişilerin suçlarıyla daha fazla ilgilendikleri ve yoksulluğa özel bir vurgu yaptıkları görülmektedir. Suç kuramlarının yoksulluk vurgusu önemli görünmekle beraber, yoksulların yaşam mücadelelerinde başvurdukları diğer yollara/çarelere değinmemeleri, büyük bir eksiklik olarak karşımızda durmaktadır.

Yoksulluk dinamik bir olgu, yoksullar da hareketli bir kitle oldukları için, farklı zaman ve yerlerde yoksulların hayatta kalmak veya yaşamlarını iyileştirmek için birbirinden farklı birçok 
yola başvurduklarını görmekteyiz. Yoksullar, gerek evde, gerekse sokakta sorunlarına çare aramakta, Bayat'ın (2008: 28-29) belirttiği gibi, çoğu zaman gayrimeşru yollara başvurmaktadırlar. Kimi zaman arazi işgalleri ve yasa dışı inşaatlar yaptılar; kimi zaman gayri resmi yerleşimlerini bürokratlara rüşvet vererek elde ettiler; kimi zaman elektrik ve su gibi hizmetleri kaçak yollardan temin etmeye çalıştılar; kimi zaman sokakları işgal edip işportacılık ve sokak satıcılığ 1 gibi işler yaptılar; kimi zaman yardım almak için aile, akraba ve arkadaş desteğine başvurdular; kimi zaman da direniş tarzındaki sokak eylemlerine katıldılar.

Bütün bu uygulamalar, yoksulların "lümpen proletarya" veya "tehlikeli sınıflar"a ait yıkıcı davranış tarzlarından uzak olduklarını göstermektedir. Bayat’a göre bu pratikler, "söz hakkından mahrum olanların zorlukları aşmak ve daha iyi bir hayat sürmek amacıyla başvurdukları doğal ve mantıklı yolları temsil etmektedir" (Bayat, 2008: 31). Bayat'a göre, suça bulaşmaktan ziyade yoksullar, sessiz tecavüzde bulunurlar. "Sıradanın sessiz tecavüzü" olarak tanımlanan bu olgu, Bayat'a göre aslında bir mücadele biçimidir- "sıradan insanların zorlukları aşmak ve daha iyi bir yaşam sürdürebilmek için mülk sahibi ve güçlülerin üzerine sessiz, sabırll, uzun soluklu ve ssrarlı yürüyüşü" (Bayat, 2008: 35).

"Sözde vatandaşlar" olarak nitelendirdiği yoksulların ve diğer dışlanmış grupların Bayat, iki temel hedefleri olduğunu belirtmektedir: yeniden bölüşüm ve özerklik. "İlki, hayatta kalmayı ve daha iyi bir maddi yaşamı sağlarken, ikincisi kendi başına bir hedef olduğu gibi yeniden bölüşümün sağlanmasında da bir araçtır” (Bayat, 2008: 41). Bayat ayrıca, özellikle Ortadoğu kültüründe yaşayan yoksul insanların adalet anlayışına ${ }^{2}$ değinmekte; bu anlayışın da mecburiyet (haysiyetli yaşama mecburiyeti) kavramı etrafinda döndügünü belirtmektedir. Dolayısıyla, bu adalet anlayışına göre, temel bir ihtiyacı olan birisi- yasa dışı biçimde de olsa- kendi durumunda olan diğerlerine zarar vermediği sürece bu ihtiyacını karşılayabilir ve karşılamalıdır (Bayat, 2008: 41-42). Şüphesiz hukuk sistemlerinde yasa dış1 yollara başvurmak, suç olarak algılanmaktadır. Ancak, bu yasa dışı yolların (arazi ve sokak işgali, gecekondu inşa etmek, kaçak elektrik ve su kullanmak vb.) çoğu zaman siyaset mekanizmalarınca görmezden gelindiği ve bazen de popülist politikalara malzeme yapıldığı görülmektedir. Dolayısıyla, hukuken suç teşkil eden bazı eylemler, politik çıkarlara hizmet ettiği için, siyasi ve toplumsal açılardan hoş görülmektedir. Devlet, herhalde suçluluk psikolojisiyle, bu insanlara dokunmamanın ve onların geliştirdiği geçim stratejilerine saygı duymanın daha makul olduğunu düşünmektedir.

Bununla birlikte bu, yoksulların cezai yaptırım gerektiren eylemlere hiç bulaşmadıkları ve hep aynı tarzda davrandıkları anlamına gelmemektedir. Kanaat, paylaşma ve azla yetinme gibi değerlerin yoksullar arasında kaybolduğu bir ortamda, özellikle neredeyse kuralsızlığın kural haline geldiği kentsel ortamlarda, kent yoksullarının oluşturduğu bir "kuralsız yoksulluk"tan (Iş̧1k ve Pınarcıoğlu, 2003) söz etmek mümkündür. Bugün yoksullar artık kaderlerine razı olmamakta, başta enformel sektör olmak üzere çeşitli hayatta kalma ve geçinme yollarına başvurarak daha yırtıcı ve saldırgan olabilmektedirler (Işık ve Pınarcıoğlu, 2005: 76).

Sonuç olarak, günümüzde yoksulların yaşam alanlarının giderek daraldığı ve onların birçok olumsuz durumla karşı karşıya kaldıkları görülmektedir. $\mathrm{Bu}$ durumlar karşısında yoksullar kabuklarına çekilip duyarsızlaşmamakta (şüphesiz bu durumda olan yoksullar da var), aksine hayata katılıp çeşitli geçinme yolları geliştirip, yasa dışı yollara başvurup, sessiz tecavüzde bulunup, belki de suçlu eylemlere katılıp aktif bir yaşam mücadelesi vermektedirler. Onlar hayatın zorlukları karşısında bazen suç işlemişlerdir. Ancak bu, kültürden kültüre değişmekle birlikte, belki de yoksulların başvurdukları son çaredir. Dolayısıyla, yoksullukla suç arasında doğrusal bir ilişkinin var olduğunu kabul etmek mümkün görülmemektedir.

\footnotetext{
${ }^{2}$ Lee ise düşük statülü grupların şiddet kullanımına göz yuman, hatta şiddet kullanımını teşvik eden bir "onur ahlâkı" geliştirdiklerini belirtmektedir. Lee’ye göre bu, düşük statülü grupların bir özelliğidir (Lee, 2000: 193).
} 


\section{KAYNAKÇA}

AGNEW, R. (2009), "Strain Theories", 21st Century Criminology-A Reference Handbook, Ed. J. Mitchell Miller, New Delhi: SAGE Publications, 332-339.

ASLANOĞLU, R. A. (2000), Kent, Kimlik ve Küreselleşme, 2. Baskı, Bursa: Ezgi Kitabevi.

BALCI, Ş. G. (2007), Tutunamayanlar ve Hukuk, Ankara: Dost Kitabevi.

BAYAT, A. (2008), Sokak Siyaseti- Iran'da Yoksul Halk Hareketleri, Çev. Soner Torlak, Ankara: Phoenix Yayınevi.

BAYAT, A. (2006), Ortadoğu'da Maduniyet- Toplumsal Hareketler ve Siyaset, Der. Özgür Gökmen ve Seçil Deren, İstanbul: İletişim Yayınları.

BECKER, H. S. (196), Outsiders: Studies in the Sociology of Deviance, New York: Free Press.

BUĞRA, A. (2008), Kapitalizm, Yoksulluk ve Türkiye'de Sosyal Politika, İstanbul: İletişim Yayınları.

FERRELL, J. (2009), "Cultural Criminology”, 21st Century Criminology-A Reference Handbook, Ed. J. Mitchell Miller, New Delhi: SAGE Publications, 219-227.

FOUCAUlT, M. (2006), Hapishanenin Doğuşu, 3. Baskı, Çev. M. Ali Kılıçbay, Ankara: İmge Kitabevi.

FRIEDRICHS, D. O. (2009), "Criticial Criminology", 21st Century Criminology-A Reference Handbook, Ed. J. Mitchell Miller, New Delhi: SAGE Publications, 210-218.

FUCHS, R. G. (2005), Gender and Poverty in Nineteenth-Century Europe, New York: Cambridge University Press.

GEREMEK, B. (1994), Poverty: A History, Translated by Agnieszka Kolakowska, Oxford, U.K.: Blackwell.

GIDDENS, A. (2008), Sosyoloji, Yay. Haz. Cemal Güzel, İstanbul: Kırmızı Yayınları. Yayınları.

GORZ, A. (2001), Yaşadığımız Sefalet- Kurtuluş Çareleri, Çev. Nilgün Tutal, İstanbul: Ayrıntı

IŞIK O., PINARCIOĞLU, M. M. (2005), Nöbetleşe Yoksulluk: Sultanbeyli Örneği, 5. Baskı, İstanbul: İletişim Yayınları.

IŞIK O., PINARCIOĞLU, M. M. (2003), "Nöbetleşe Yoksulluktan Kuralsız Yoksulluğa”, Görüş, Temmuz Sayıs1, 50-53.

KIZMAZ, Z. (2006a), Cezaevi Müdavimleri- İnatçı Suçlular, Ankara: Orion Yayınevi.

KIZMAZ, Z. (2006b), "Kriminolojide Yeni Yönelimler: Bütünleşik (Integrated) Suç Kuramlar1- II”, F. Ü. Sosyal Bilimler Dergisi, 16 (1), 305-335.

KIZMAZ, Z. (2005), "Sosyolojik Suç Kuramlarının Suç Olgusunu Açıklama Potansiyelleri Üzerine Bir Değerlendirme”, C. Ü. Sosyal Bilimler Dergisi, 29 (2), 149-174.

LEE, M. R. (2000), “Concentrated Poverty, Race, and Homicide”, The Sociological Quarterly, 41 (2), 189-206. Books.

LEWIS, O. (1959), Five Families: Mexican Case Studies in the Culture of Poverty, New York: Basic

MADDAN, S., MARSHALL, I. H. (2009), "Labelling and Symbolic Interaction Theories", 21st Century Criminology- A Reference Handbook, Ed. J. Mitchell Miller, New Delhi: SAGE Publications, 253261.

MARSH, I., vd. (2006), Theories of Crime, Ed. Ian Marsh vd. New York: Routledge.

MERİÇ, C. (1999), Saint-Simon- İlk Sosyolog İlk Sosyalist, 5. Baskı, İstanbul: İletişim Yayınları.

POLANYI, K. (2000), Büyük Dönüşüm, Çev. Ayşe Buğra, İstanbul: İletişim Yayınları. 
RAHNEMA, M. (2009), Sefaletin Yoksulluğu Kovduğu Bir Dünya, Çev. Şule Ünsaldı, Ankara: Özgür Üniversite Kitaplığı.

RITZER, G. (2011), Küresel Dünya, Çev. Melih Pakdemir, İstanbul: Ayrıntı Yayınları.

ROBERT, J. ve RAHNEMA, M. (2011), Yoksulların Gücü, Çev. Şule Ünsaldı, Ankara: Özgür Üniversite Kitaplı̆ğ.

SIEGEL, L. J. (2011), Criminology- The Core, fourth Edition, USA: Wadsworth Cengage Learning.

SLATTERY, M. (2008), Sosyolojide Temel Fikirler, 2. Bask1, Yay. Haz. Ümit Tatlıcan ve Gülhan Demiriz, Bursa: Sentez Yayıncılık.

TUNA, K. (2013), Toplum Açılklama Girişimi Olarak Şehir Teorileri, 2. Baskı, İstanbul: İz Yayıncılık.

TÜRKDOĞAN, O. (2006), İstanbul Gecekondu Kimliği, İstanbul: IQ Kültür Sanat Yayınc1lık.

YILMAZ, Z. (2012), Yoksulları Ne Yapmalı?, Ankara: Dipnot Yayınları. 
